\title{
Notions of Solidarity and Integration in Times of War: The Idea of Europe, 1914-1918
}

This article argues that Europe remained present during some of the Continent's darkest years in recent history. Arguably, the First World War did not just aggravate nationalist sentiments and xenophobic tendencies but also encouraged intercultural exchange and a better understanding of other societies and ways of life. Indeed, the wartime prevalence of notions of solidarity and integration requires more attention and careful analysis. The essay explores three key issues, focusing in particular on solidarity practices and transnational interaction. It investigates military alliances, the collaboration between national independence movements, and the role of neutral countries as refuge and gathering place of pacifist groups and intellectuals. Many of these actors discussed and promoted forms of at least regional cooperation in post-war Europe.

Keywords: Solidarity, European history, First World War, internationalism, military alliances, independence movements, neutrality, pacifism

\section{Introduction}

Writing shortly before the end of the First World War, the Czech philosopher and statesman Tomáš G. Masaryk expressed his conviction that the conflict and its consequences 'brought mankind closer together': 'Internationalism, more intimate than ever, has been fostered by this war'. ${ }^{1}$ Given the destruction and suffering caused by more than four years of industrialised warfare and economic hardship, such a statement will surprise many and seem hardly credible. Scholars have, quite understandably, tended to focus on the nationalism and hatred in the belligerent countries, holding that it led to a fundamental rupture of any sense of European solidarity and unity. While this is true for broad sections of public (and private) opinion, there was a considerable number of dissenting Europeanist voices which have been largely ignored by academic research. Indeed, most historians of the idea of Europe cover the period of the First World War only briefly, and JeanBaptiste Duroselle even stated that 'there was no Europe between 1914 and 1919'.2 But the war did not cut off all international links and in fact created many new ties of friendship and support. This article demonstrates these points by exploring three main topics, focusing on practices of solidarity, transnational interaction and coordination, and plans for future cooperation, rather than on the actual use of the term 'solidarity' by contemporaries. In a first step, it will examine the arguably most obvious but nevertheless widely overlooked bond of solidarity and community during the war, namely military alliances. The essay will then discuss the shared aspirations and joint activities of East-Central European independence movements, before considering the role of neutral countries, pacifist groups, and émigré intellectuals in preserving and promoting a spirit of continental unity and peace. 


\section{The Breakdown of Pre-War Internationalism}

The period before the outbreak of the First World War is often described as an age of Great Power rivalry and imperial competition, leading to a marked deterioration of European affairs since at least 1890. The emergence of an antagonistic alliance system and a series of diplomatic crises over North Africa and the Balkans, the increasing militarisation of many societies, and the rise of popular nationalist movements all seem to indicate an almost inevitable path towards a major international conflict. ${ }^{3}$ Such conventional views have more recently been challenged by a number of historians, who have pointed to counter-tendencies and various efforts aiming at rapprochement and mutual understanding, such as the two international peace conferences in The Hague (1899/1907), the Anglo-German détente prior to 1914, or the rise of pacifist movements at the turn of the century. ${ }^{4}$ Other scholars have highlighted the internationalisation of European societies as a consequence of certain technological innovations and the growth of a more mobile and wellinformed middle class. ${ }^{5}$ Despite some setbacks and slumps, and the persistence or revival of trade protectionism, European economies became more interlinked than ever before. These trends often had a marked global dimension, but still applied primarily to the Continent, as evidenced by the various trade fairs or transnational networks of businessmen, academics, and intellectuals. Charles Emmerson, for instance, has described the pre-war years as 'a period of unprecedented globalisation, rich in encounters, interconnections and ideas', but also underlined that Europe was 'the engine room of these developments. ${ }^{6}$ While those years were characterised by a notable lack of European idealism and proposals for continental integration, especially when compared to the first half of the nineteenth century or the interwar period, there were a number of projects and institutions more limited in scope and purpose, such as the European Danube Commission (1856), the International Telegraph Union (1865), the Universal Postal Union (1874), or the Central Office for International Railway Transport (1893). It was against this background of increased economic and financial interdependence that the British journalist Norman Angell held war unprofitable and disastrous. ${ }^{7}$ All this went hand in hand with strong self-confidence, a belief in European superiority and the right (if not duty) to civilise non-European territories and peoples. In his autobiography The World of Yesterday (1942), the Austrian writer Stefan Zweig later described the emergence of a 'European community spirit' and 'European national consciousness' in the prewar period: 'Never had Europe been stronger, richer, more beautiful, or more confident of an even better future.' ${ }^{8}$ The picture Zweig painted was of course a glorifying and nostalgic one, expressing the longing for a seemingly peaceful, prosperous, and tolerant past that had vanished forever. It is indeed important not to generalise and overstate the degree of internationalisation and contact, given the major regional and socio-economic differences within Europe. On the other hand, there was a widespread awareness that the outbreak of the war in summer 1914 represented a fundamental rupture in European relations, cutting those ties of friendship, cooperation, and trust between individuals and communities. This also applied to three of the most prominent roots or circles of international solidarity in pre-war Europe: long-standing dynastic links and interests, shared religious beliefs and practices, and the camaraderie and collective class consciousness of organised labour. Already in decline since the second half of the nineteenth century and regardless 
of close family ties between Europe's royal houses, the concept of monarchical solidarity, i.e. of jointly embodying and defending the principles of legitimate rule, political integrity, and historical continuity, proved empty in $1914 .{ }^{9}$ In spite of the central doctrines of universal Christian unity and brotherhood, and various ecumenical initiatives in the pre-war period, such as the World Student Christian Federation (1895) and The World Alliance for Promoting International Friendship through the Churches (1914), most religious groups and institutions quickly rallied behind the cause of the fatherland. They contributed significantly to the spiritual mobilisation of state and society by justifying the war as just and calling for individual and collective sacrifices in the name of God and the nation. As the German court chaplain Ernst Dryander preached on 4 August 1914: 'God will be with our just weapons! For German faith and German piety are intimately bound up with German civilisation. ${ }^{10}$ Despite large anti-war demonstrations in numerous European cities, involving 750,000 people in Germany alone, the international solidarity of the working class broke down upon the outbreak of war, too, as most labour activists bought into the notion of a defensive war and thus supported the national war effort. Following London's entry into the war, Fenner Brockway, the editor of the newspaper of the Independent Labour Party, was one of the few voices left who argued that British workers had 'no quarrel' with the workers in other countries: 'The quarrel is between the ruling classes of Europe. Don't make this quarrel yours'. ${ }^{11}$ As we will see in the following, while the beginning of hostilities did bring an end to many established forms of European cooperation and dialogue, new ideals and practices of cross-border interaction emerged relatively quickly.

\section{Brothers in Arms: Military Alliances and Plans for European Integration}

Most of the European great powers were multi-ethnic entities, and - apart from the Habsburg Monarchy - as imperial domains that stretched across continents, they quickly turned the military conflict into a global affair. This alone should warn us against studying the war in purely European terms and against overemphasising elements of national (or nation-state) antagonism and isolation. ${ }^{12}$ Moreover, while military conflicts undoubtedly foster feelings of enmity and hatred, they can also encourage intercultural understanding and interaction, especially amongst military allies and international partners. The First World War was, above all, a war of coalitions, and even though it often proved difficult to establish a unified alliance strategy under joint leadership given the differences in operational aims, manpower, equipment, training, and morale, the fundamental

principle of solidarity and mutual support remained significant and often decisive. ${ }^{13}$ During the war, Germany found itself allied not only to its Zweibund partner, Austria-Hungary, but also to the Ottoman Empire (since October 1914), a Muslim realm which had repeatedly posed an existential threat to European Christianity and independence, and to Bulgaria (since September 1915), a Slav country with Russophile sentiments. Nevertheless, many German politicians and intellectuals celebrated the war alliance with Constantinople and Sofia as an organic union, 'a natural coalition' of younger, unspoilt and authentic nations fighting for the defence of European culture and civilisation against Russian 'barbarism' and the materialism and decadence of the Western 
democracies. ${ }^{14}$ While the Bulgarians were now portrayed as westward-looking 'Prussians of the Balkans', some authors declared their solidarity with oppressed Muslims under the rule of the Entente powers and supported German-Ottoman efforts to incite a religious war (jihad). ${ }^{15}$ Many commentators were also well aware of the Habsburg ally's multinational character and recognised the war effort of the Austro-Slavs and the Magyars. ${ }^{16}$ From early on, Germany assumed a role as protector and liberator of non-Russian nationalities in the western territories of the Tsarist Empire, and pursued various other initiatives to revolutionise the enemies' colonial areas and to undermine the imperial fabric there, including attempts to offer military aid to Irish nationalists. The most successful of these efforts was the transport of Lenin in a sealed train from his exile in Switzerland to Petrograd in April 1917, thus unleashing the 'most grisly of all weapons', as Winston Churchill later recalled. ${ }^{17}$

There were similar endeavours on the side of the Entente with regard to Arab tribes in the Ottoman Empire and some East-Central European peoples under Habsburg rule, a point discussed in greater detail below. One of the key arguments for London's involvement in the war had been the defence of Belgian independence, and the Western powers quickly presented themselves as guardians of European civilisation, freedom, and democracy against Prusso-German militarism and autocracy. As Prime Minister Herbert Asquith declared on 6 August 1914, Britain was entering the war in order to defend the rights and independence of small nationalities: 'I do not believe any nation ever entered into a great controversy ... with a clearer conscience and a stronger conviction that it is fighting, not for aggression, not for the maintenance even of its own selfish interest, but that it is fighting in defence of principles the maintenance of which is vital to the civilisation of the world. ${ }^{18}$ Up to 250,000 Belgians found refuge in allied Britain, with an even higher number settling in France (while the rest of the total number of c. 600,000 refugees went to the Netherlands). ${ }^{19}$ Entente politicians and publicists also celebrated their coalition, although Russia seems to have been mentioned less often. Some French and Italian intellectuals glorified the brotherhood between Latin belligerent countries by employing a peculiar mixture of national(ist) and transnational arguments that was also characteristic for other Pan-nationalist movements. ${ }^{20}$ It was, however, the Franco-British relationship that stood at the centre of the discourse of comradeship and solidarity amongst the Entente allies, at least up to the US-American entry into the war in early 1917. In a series of articles published in the Daily Telegraph in September 1915, Rudyard Kipling, the popular writer and ardent defender of British imperialism who was now working for the War Propaganda Bureau at Wellington House, praised the French for fighting 'on the frontier of civilisation' against those German 'brutes yonder': 'It is the rampart put up by Man against the Beast, precisely as in the Stone Age.' He showed himself impressed by 'that iron nerve and endurance and faith which is the new inheritance of France' and argued that 'there is only one world today, the world of the Allies': 'Each of them knows what the others are doing and - the rest doesn't matter. This is a curious but delightful fact to realise at first hand. And think what it will be later, when we shall all circulate among each other and open our hearts and talk it over in a brotherhood more intimate than the ties of blood!'. ${ }^{21}$ 
It was against this background of coalition warfare and alliance rhetoric that schemes for more permanent political and economic cooperation were put forward by politicians and publicists, such as the idea of a Central European economic association, commonly known as Mitteleuropa. ${ }^{22}$ Friedrich Naumann, for instance, who was one of the foremost advocates of the project in Germany, portrayed his plan as the continuation or consequence of the wartime solidarity and comradeship-in-arms between the Central Powers: 'We fight as Germans, but we fight with millions of non-Germans, who are prepared to go with us to battle and to death, so long as they have our respect and can believe that our victory will also be their victory. ${ }^{23} \mathrm{We}$ can find similar, though less far-reaching ideas of economic integration and continental solidification amongst the allied democracies, in particular in France. This was partly a reaction to the German scheme and intended to guarantee self-sufficiency and closer cooperation also after the war, but the proposition to perpetuate economic warfare beyond the end of hostilities met resistance in London, Rome, and St Petersburg. Still, it re-emerged in more concrete forms in summer 1918, and David Stevenson is right in pointing out that 'a project for a Western European union appears first to have circulated in the Paris bureaucracy not in $1929-30$ or 1950 but in $1918 .^{24}$

\section{The 'New Europe': National Independence Movements in East-Central Europe}

'Everywhere the weak, oppressed, and exploited unite themselves - association is the watchword of our era: federation, the free federation of small nations and states will be the consummation of this principle securing the final organization of the whole of mankind. ${ }^{25}$ This is how Masaryk described the wartime cooperation between various separatist movements in Central and Eastern Europe, aimed against (and transcending the borders of) the Russian and Habsburg Empires. It markedly went beyond pre-war contacts between activists in the region who had long demanded enhanced autonomy within the imperial framework rather than full national independence. ${ }^{26}$ But the protracted duration of the war, the scale of casualties and material hardship, and increased political repression led to a radicalisation of demands, as shown for instance at the re-opening of the Austrian Reichsrat in May 1917. ${ }^{27}$ Encouraged by the military successes of the Central Powers in Eastern Europe and domestic problems within the Tsarist Empire, non-Russian nationalities were equally hoping for political liberation from 'foreign rule'. Exile activists, who promoted their national cause abroad, were crucial for these efforts. While some Poles such as Józef Piłsudski sought the support of Berlin and Vienna for the re-unification of Poland, Roman Dmowski and others sided with the Entente, setting up the Polish National Committee and liaising with a number of other pro-independence émigrés from the Habsburg Monarchy, including Ante Trumbić and Frano Supilo from the Yugoslav Committee or Masaryk and Edvard Beneš from the Czechoslovak National Council. In April 1918, they famously met at the Rome Congress of Oppressed Nationalities and passed a joint declaration, calling for the dissolution of Austria-Hungary and national self-determination. Having quickly gained the support of influential publicists in France and the United Kingdom (such as Robert William Seton-Watson), by summer 1918 the exile politicians received official recognition as de-facto governments of their respective homelands. ${ }^{28}$ 
Woodrow Wilson, too, who had initially envisaged greater national equality within the existing state entities (although his Fourteen Points of January 1918 already demanded an independent Poland), eventually backed national independence and a territorial reconfiguration of Central and Eastern Europe. ${ }^{29}$ However, there were also several concepts for long-term regional integration beyond this wartime cooperation. The Corfu Declaration of July 1917 envisaged a united Southern Slav Kingdom of Serbs, Croats and Slovenes. Taking up federalist ideas of the pre-war period and often referring back to the Polish-Lithuanian Commonwealth, Polish intellectuals and politicians such as Leon Wasilewski promoted an East-Central European union, comprising Polish, Lithuanian, Ukrainian, and Belarussian territories. ${ }^{30}$ Following earlier Czech-Polish discussions

and embracing Wilsonian ideals, the Mid-European Union was established in Philadelphia in October 1918, a loose (and short-lived) political association that was supported by a number of national representatives (including Romanians, Greeks, and Italians). Integration plans were repeatedly debated at the meetings, but the scope and form of future cooperation remained contested. Ultimately, the delegates pronounced in rather vague terms that 'our peoples, having kindred ideals and purposes, should coordinate their efforts to insure the liberties of their individual nations for the furtherance of their common welfare'. ${ }^{31}$ Masaryk, who was one of the signatories of the document, had long promoted similar ideas in his publications. His New Europe (1918) envisaged a political reorganisation of the area between Germany and Russia to counter Prussian militarism and Habsburg absolutism: a liberal-democratic association of free and equal nations, although he remained sceptical about joint institutions and supranational arrangements. ${ }^{32}$

\section{The European 'Civil War': Wartime Neutrality and Pacifism}

The significance of neutral countries for the course and outcome of the First World War has only recently been grasped more fully. ${ }^{33}$ They certainly posed a particular challenge to wartime propaganda and diplomacy, cutting across the conventional 'us versus them' dichotomy. Six European states remained neutral for the whole period, i.e. the three Scandinavian countries (Finland was part of the Russian empire until December 1917), Spain, Switzerland, and the Netherlands. Together with the International Red Cross and the Vatican, they took an active role in humanitarian relief efforts, for instance with regard to the treatment of prisoners of war, the delivery of food to areas under German occupation, or the provision of medical aid and personnel. ${ }^{34}$ Interestingly, several neutrals attempted to form some sort of an alliance or grouping to coordinate their work and to protect their political and commercial rights (e.g. against the naval blockade), with the Scandinavian countries joining forces early on but ultimately failing to win over the United States and other states. ${ }^{35}$ It was in particular via these channels that the antagonistic powers stayed in contact with each other and effected various peace efforts (while some neutrals started initiatives of their own, in particular the United States and the Vatican). In early 1915, for instance, Berlin approached Russia about the possibility of a separate peace by way of Danish intermediation, and in late 1917 it asked the Spanish minister to Belgium to facilitate peace communications with Britain. ${ }^{36}$ Neutral countries also served as host and focal point of pacifist 
initiatives which tried to maintain international friendship and cooperation across the frontlines. The Dutch Anti-War Council (Nederlandsche Anti-Oorlog Raad, NAOR), a loose organisation of more than 10,000 members, was arguably the most significant of these. In early 1915, it helped to organise two international gatherings in The Hague, a large pacifist convention (leading to the formation of the Central Organisation for a Durable Peace) and the Women's Peace Congress shortly afterwards. ${ }^{37}$ At the same time, several left-wing Socialists from both belligerent and neutral countries were trying to re-connect and to establish a common platform against the war and its underlying 'capitalist' causes, meeting twice in Switzerland in September 1915 (Zimmerwald) and April 1916 (Kiental). A similar, cross-national peace conference of moderate Socialists was to take place in Stockholm in June 1917 but failed to materialise due to resistance from the Entente governments. Indeed, as the Petrograd Soviet had publicly and rather ominously appealed 'to the peoples of all the world' in March 1917: 'The time has come to begin a decisive struggle against the acquisitive ambitions of the governments of all countries; the time has come for the peoples to take into their own hands the decision of the question of war and peace.' 38

It was also here, on neutral territory, where some of the most important and passionate Europeanist responses to the war were articulated. Co-founded by the Dutch writer Nico van Suchtelen, De Europeesche Statenbond, for instance, promoted a European federation and gained the support of numerous intellectuals and publicists abroad. ${ }^{39}$ It greatly influenced NAOR which included the demand for a united Europe in its programme. In Spain, Eugenio d'Ors lamented the conflict as a European 'civil war' and established a Committee of Friends for the Moral Unity of Europe, whose famous manifesto was widely translated and read. ${ }^{40}$ Numerous Swiss intellectuals, too, amongst them Georg Wettstein, Otfried Nippold, and Emil Rüegg, promoted European reconciliation and understanding. ${ }^{41}$ Johannes Erni even elaborated a constitutional draft for a European Union with joint institutions (including a legislative assembly) in Berne. ${ }^{42}$ Not surprisingly, Europeanist voices in belligerent countries were scarce in comparison. Various intellectuals and politicians such as Bertrand Russell and Edmund Morel, two prominent members of the British Union of Democratic Control, but also Charles Gide, Paul Valéry, Hellmut von Gerlach, René Schickele, and Benedetto Croce did defend and emphasise notions of European unity and commonality, but their views remained marginal in societies that were united in their desire to crush the enemy. Most of their peers, in fact, subscribed to the idea that the war represented a fundamental struggle between the ideas of 1789 and those of 1914, between German Kultur and Western civilisation, holding that their own side represented the genuine ideals and values of Europe. ${ }^{43}$ In order to escape this nationalistic atmosphere and, in some cases, political persecution, several literary and public figures went into exile to neutral states, most notably Switzerland, which offered better publishing opportunities and allowed the direct exchange with like-minded war critics from enemy countries. Indeed, it was in Switzerland where the German physician Georg Friedrich Nicolai printed his famous book on The Biology of War for which he was to be tried at home, only narrowly escaping to Copenhagen in summer 1918. The volume contained his 'Aufruf an die Europäer', a counter-declaration against the nationalistic manifesto of 93 German intellectuals of October 1914. ${ }^{44}$ Alfred Hermann Fried, the Nobel Peace Prize 
awardee of 1911 and editor of the Friedenswarte, the leading pacifist periodical in the German language, had moved to Switzerland already in late 1914 in order to continue his work. He also published his call for the 'Reconstruction of Europe' here, suggesting a federation after the USAmerican model to secure peace and prosperity on the Continent. ${ }^{45}$ Romain Rolland, too, who has been described as 'the voice of Europe in the season of its most poignant agony', the 'conscience of the world', resided in Switzerland from where he worked tirelessly against the war and for European reconciliation. ${ }^{46}$ Shunned by many of his French compatriots, he pointed to the historical and cultural commonalities between the belligerent nations, hoping to re-instil a European sense of togetherness across borders and cultures. ${ }^{47}$

\section{Conclusion}

The aim of this essay was not to present a comprehensive analysis of the idea (or ideas) of Europe during the First World War, especially not in the sense of a more or less conventional intellectual history. Rather, it tried to demonstrate the persistence of elements of commonality and cooperation within Europe. The notion of solidarity was central in this regard, but in very different ways. In the first two cases, i.e. military alliances and national independence movements, a certain group joined forces against a concrete other, be it the military enemy or foreign domination and imperial rule, in order to further the state-political or ethno-national self-interest. The mutual support and joint efforts focused on distinct regions or parts of Europe: the Anglo-French military partnership, Friedrich Naumann's Mitteleuropa, or plans to liberate the oppressed nationalities under Habsburg and Tsarist rule in East-Central Europe were mentioned in this context. ${ }^{48}$ There usually was a possibility of extension and affiliation of further members, provided the values, interests, and aims of the group were shared, such as liberal democracy and the recognition of the right of national self-determination, but schemes and ideas of a more comprehensive continental integration presupposed decisive military victory over the other. Insofar, this was solidarity in practice, promoted primarily by statesmen, diplomats, and military leaders, although it was underpinned and justified by an intellectual discourse that highlighted commonalities and requested sacrifices for the common good, often describing the own effort as part of a mission to save or regenerate Europe. While notions of European identity and unity were thus also prominent in the statements and writings of many nationalists, they played a much more significant role for many pacifist thinkers and activists. Solidarity here was inherently peaceful, non-hierarchical, inclusive, and utopian, aimed less against a concrete other but against war and violence in general. It was based on moral imperatives and the fundamental respect for human rights and international justice, rather than on the pursuit of specific group interests and political goals. We certainly should be careful not to overstate the short- and long-term impact of these ideas. Altogether, Europe emerged weakened, impoverished, and disjointed from the chaos of war and revolution. Following the break-up of the Habsburg, Russian, and Ottoman empires, and the substantial curtailment of German power, continental geopolitics differed considerably from the pre-war situation. The stipulations of the Paris Peace Treaties led to much resentment and revisionist ambitions amongst 
the defeated (and indeed some of the victorious) powers, destabilising the new liberal-democratic regimes there and impeding European reconciliation for many years to come. The recognition and (often contested) application of the right of national self-determination quickly led to new turmoil and violence in the East-Central European area, although ideas of regional cooperation survived in the form of the 'Little Entente' and designs for a Danubian confederation. ${ }^{49}$ More generally, the two Russian revolutions - signifying the beginning of a long period of fundamental ideological shifts and conflicts - and the involvement of the United States had changed the parameters of the discourse on European unity and cooperation significantly. President Wilson promoted a global solution to the question of peace and stability in Europe, even though a league of nations did not necessarily rule out continental integration and was in fact popular with many pacifists and Europeanists, such as Rüegg, Nippold, and Fried. ${ }^{50}$ The Catholic and Socialist concepts of international solidarity, more influential again from c. mid-1917 as a consequence of the growing war weariness and political dissent in many belligerent countries, were in any case universal rather than narrowly European in principle. At the same time, Europe's status in the world was clearly on the wane. While Britain and France were able to maintain and even expand their imperial rule (via the post-war mandate system), their empires were far from secure. Wilsonian ideals of internationalism and independence resonated much more with the colonial world than traditional claims of European moral and civilisational superiority. ${ }^{51}$ The painful experience and difficult legacy of the First World War, the concomitant rise of US-American and Japanese economic and political power, and the widespread fear of (further) European decline produced one of the most intense debates on continental unification and cooperation in European history, although without much practical relevance. ${ }^{52}$ It took another major and even more devastating military conflict before some of these ideas were adopted.

\footnotetext{
${ }^{1}$ Masaryk, Das neue Europa, 10.

${ }^{2}$ Duroselle, L'idée d'Europe, 261. Pegg devotes merely six pages to the war in his Evolution of the European Idea, 8-13. Also see Curcio, Europa, 789-98; de Rougemont, Idea of Europe, 33536; Bugge, "The Nation Supreme"; Stirk, History of European Integration, 20-21. The various contributions to Spiering and Wintle, eds., Ideas of Europe since 1914, focus on the consequences of the war rather than on the conflict itself.

${ }^{3}$ Eric J. Hobsbawm, for instance, speaks of 'a slow slide towards the abyss' before 1914: Hobsbawm, Age of Empire, 311.

${ }^{4}$ Kießling, Gegen den 'großen' Krieg?; Afflerbach and Stevenson, eds., An Improbable War?; Beatty, Lost History.

${ }^{5}$ Bayly, Birth of the Modern World; Osterhammel, Verwandlung der Welt; Illies, 1913.

${ }^{6}$ Emmerson, 1913, xiii, 3.

${ }^{7}$ Angell, The Great Illusion.

${ }^{8}$ Zweig, World of Yesterday, 196, 193.
} 
${ }^{9}$ Otte, "The Waning of the Monarchies". I am very grateful to T.G. Otte for making his essay available to me before publication. Also see Kann, "Dynastic Relations".

${ }^{10}$ Quoted from Scholder, Churches and the Third Reich, 6. Also see Krumeich, "'Gott mit uns'?"; Lehmann, "International Solidarity"; Becker, "Faith, Ideologies, and the "Cultures of War"; Gregory, "Beliefs and Religion".

${ }^{11}$ Quoted from Zurbrugg, ed., Not Our War, 7. On organised labour and socialist movements before 1914, see Geary, ed., Labour and Socialist Movements and Berger, "Labor Movements". ${ }^{12}$ See, for instance, Morrow, Great War; Sondhaus, World War One; Gerwarth and Manela, eds., Empires at War.

${ }^{13}$ See, with further references, Neiberg, "Commanding through Armageddon" and Vermeiren, First World War.

${ }^{14}$ [Arthur] Moeller van den Bruck, "Schicksal ist stärker als Staatskunst," Deutsche Rundschau, November 1916, 161-7 (p. 165).

${ }^{15}$ Ernst v. R[eventlow], "Das siegreiche Bulgarien,” Deutsche Tageszeitung, 29 December 1915. Also see Schweitzer, Bulgarienbild; Heeresgeschichtliches Museum, ed., Der unbekannte Verbündete; Stein, “'Wer das nicht mitgemacht hat, glaubt es nicht”. On German-Turkish relations, see most recently Lüdke, Jihad Made in Germany; Will, Kein Griff nach der Weltmacht; Loth and Hanisch, eds., Erster Weltkrieg und Dschihad.

${ }^{16}$ Vermeiren, First World War, 73-119, 183-222.

${ }^{17}$ Churchill, World Crisis, 73.

${ }^{18}$ War Speeches by British Ministers, 8.

${ }^{19}$ Amara, Des Belges à l'épreuve de l'Exil.

${ }^{20}$ Giladi, "L'idéologie panlatine".

${ }^{21}$ Kipling, "France at War", 116, 119, 131, 159.

${ }^{22}$ On Mitteleuropa, see Meyer, Mitteleuropa; Droz, L'europe centrale; Plaschka et al., eds., Mitteleuropa-Konzeptionen; Brandt, "Von Bruck zu Naumann".

${ }^{23}$ Naumann, Central Europe, 11. Also see Vermeiren, First World War, 145-82.

${ }^{24}$ Stevenson, "The First World War and European Integration", 856. For the broader context, see Soutou, L'or et le sang. From a more Europeanist and pacifistic (rather than state-official) point of view, such ideas of European economic integration were also promoted by C.E. Curinier and Charles Gide. On aspects of political cooperation between 1914 and 1918 and beyond, see Williams, "The Allies during the First World War".

${ }^{25}$ Masaryk, Das neue Europa, p. 72.

${ }^{26}$ Roshwald, Ethnic Nationalism.

${ }^{27}$ Zeman, Break-Up of the Habsburg Empire; Valiani, End of Austria-Hungary.

${ }^{28}$ Hanak, Great Britain and Austria-Hungary; Calder, Britain and the Origins; Seton-Watson, Making of a New Europe.

${ }^{29}$ Mamatey, United States and East Central Europe.

${ }^{30}$ Juzwenko, "Leon Wasilewski's Hopes"; Borodziej et al., "Polnische Europa-Pläne des 19. und 20. Jahrhunderts". See also Górny, "Eagle and Dwarf".

${ }^{31}$ Quoted from Gross, Crossroads of Two Continents, 88. 
${ }^{32}$ Langer, "Tomáš Garrigue Masaryk”. Also see Machovec, Tomáš G. Masaryk; Höhne, "Imperiale Ambitionen"; and Hájková, "Masaryk’s Vision".

${ }^{33}$ See, as one example, den Hertog and Kruizinga, eds., Caught in the Middle. For a recent overview with further references, see Kruizinga, "Neutrality".

${ }^{34}$ See e.g. Hinz, "Humanität im Krieg?"; Little, "Humanitarian Relief in Europe".

${ }^{35}$ Rosenbusch, "Spain's relief effort".

${ }^{36}$ Farrar, Divide and Conquer; Steglich, Friedensversuche; Hollander, Elusive Dove.

${ }^{37}$ Timmermann, Friedenssicherungsbewegungen; van der Linden, International Peace Movement. For recent overviews, see Kennedy, "Peace Initiatives", and Ceadel, "Pacifism".

38 "Soviet Appeal to the Peoples of All the World", 14 March 1917, quoted from King, "Dilemmas of a "democratic peace", 13 (my emphasis). Also see Carsten, War against War; Kirby, War, Peace, and Revolution; Nation, War on War; Nishikawa, Socialists and International Actions.

${ }^{39}$ van Suchtelen, Het eenige redmiddel.

${ }^{40}$ Fuentes Codera, "Ideas of Europe".

${ }^{41}$ Wettstein, Europas Einigungskrieg; Schweizerisches Komitee zum Studium der Grundlagen eines dauerhaften Friedensvertrages, ed., Grundlagen eines dauerhaften Friedensvertrages; Rüegg, Vereinigten Staaten. Also see Berger, Organisation der Internationalen Friedensliga and Planta, Europa auf dem Wege zur Einheit.

${ }^{42}$ Erni, Europäische Union. Also see already [Anon.], Der letzte Krieg.

${ }^{43}$ See, with further references, Prochasson, "Intellectuals and Writers" and Rasmussen, "Mobilising Minds".

${ }^{44}$ Nicolai, Biologie des Krieges.

${ }^{45}$ Fried, Europäische Wiederherstellung. For a comprehensive discussion of German pacifist circles in Switzerland, see Charrier, L'émigration allemande and idem, "Europe in German Pacifist Discourse".

${ }^{46}$ Zweig, Romain Rolland, 53.

${ }^{47}$ Several of his wartime writings are collected in Rolland, L'esprit libre. Also see his Journal des années. Standard works on Rolland include Cheval, Romain Rolland; Fisher, Romain Rolland; Klepsch, Romain Rolland. Also see Hertrampf, "Romain Rolland".

${ }^{48}$ Zweig, Romain Rolland, 53.

${ }^{49}$ On the war after the war, see now Gerwarth, The Vanquished.

${ }^{50}$ It is remarkable that none of these figures or indeed the various pacifist organisations that were mentioned above are discussed in Mark Mazower's recent history of internationalist thought and practice: Governing the World.

${ }^{51}$ Manela, The Wilsonian Moment.

${ }^{52}$ For a recent overview of developments during the interwar period (and beyond), see Hewitson and D'Auria, eds., Europe in Crisis. 


\section{Bibliography}

Afflerbach, Holger, and David Stevenson, eds. An Improbable War? The Outbreak of World War I and European Political Culture before 1914. New York: Berghahn, 2007.

Amara, Michaël. Des Belges à l'épreuve de l'Exil. Les réfugiés de la Première Guerre mondiale. France, Grande-Bretagne, Pays-Bays, 1914-1918. Brussels: Éditions de l’Université de Bruxelles, 2008.

Angell, Norman. The Great Illusion. A Study of the Relation of Military Power in Nations to their Economic and Social Advantage. New York: G.P. Putnam's Sons, 1910.

[Anon.] Der letzte Krieg! Erster Verfassungsentwurf für einen europäischen Staatenbund. Entworfen und erläutert von einem Schweizer Bürger. Zürich: Schweizer. Grütliverein, 1914.

Bayly, C.A. The Birth of the Modern World, 1780-1914: Global Connections and Comparisons. Oxford: Blackwell, 2004.

Beatty, Jack. The Lost History of 1914: How the Great War Was Not Inevitable. London: Bloomsbury, 2012.

Becker, Annette. "Faith, Ideologies, and the "Cultures of War." In A Companion to World War I, ed. John Horne. Oxford: Wiley-Blackwell, 2010: 234-47.

Berger, Emil. Die Organisation der Internationalen Friedensliga der Staaten (Societé des Nations) als Eidgenossenschaft. Ein den Freunden des Fortschrittes der Menschheit unterbreiteter Vorschlag. Zürich: Füssli, 1917.

Berger, Stefan. "Labor Movements." In A Companion to Nineteenth-Century Europe, 17891914, ed. Stefan Berger. Oxford: Wiley-Blackwell, 2006: 164-77.

Borodziej, Włodzimierz, et al. "Polnische Europa-Pläne des 19. und 20. Jahrhunderts." In Option Europa. Deutsche, polnische und ungarische Europapläne des 19. und 20. Jahrhunderts, 3 vols., eds. W. Borodziej et al., Göttingen: Vandenhoeck \& Ruprecht, 2005, I: Essays: 43-134.

Brandt, Harm-Hinrich. "Von Bruck zu Naumann. 'Mitteleuropa' in der Zeit der Paulskirche und des Ersten Weltkrieges." In Ungleiche Partner?, Österreich und Deutschland in ihrer gegenseitigen Wahrnehmung. Historische Analysen und Vergleiche aus dem 19. und 20. Jahrhundert, ed. Michael Gehler et al. Stuttgart: Steiner, 1996: 315-52.

Bugge, Peter. "The Nation Supreme: The Idea of Europe, 1914-1945." In The History of the Idea of Europe, eds. Kevin Wilson and Jan van der Dussen. London: Routledge, 1993: 83-149.

Calder, Kenneth J. Britain and the Origins of the New Europe, 1914-1918. Cambridge: Cambridge University Press, 1976.

Carsten, Francis L. War against War: British and German Radical Movements in the First World War. London: Batsford, 1982.

Ceadel, Martin. "Pacifism." In The Cambridge History of the First World War, ed. Jay Winter, Cambridge: Cambridge University Press, 2014. II: The State: 576-606.

Charrier, Landry. L'émigration allemande en Suisse pendant la Grande Guerre. Geneva: Slatkine, 2015.

Charrier, Landry. "Europe in German Pacifist Discourse during the Great War." In Visions and Ideas of Europe, eds. D'Auria and Vermeiren.

Cheval, René. Romain Rolland. L'Allemagne et la Guerre. Paris: Presses universitaires de France, 1963.

Churchill, Winston, The World Crisis: The Aftermath. London: Thornton Butterworth, 1929. 
Curcio, Carlo. Europa: Storia di un'idea. Florence: Vallecchi, 1958.

D'Auria, Matthew, and Jan Vermeiren, eds. Visions and Ideas of Europe during the First World War. Abingdon: Routledge [forthcoming].

de Rougemont, Denis. The Idea of Europe. New York: Macmillan, 1966.

den Hertog, Johan, and Samuël Kruizinga, eds. Caught in the Middle: Neutrals, Neutrality and the First World War. Amsterdam: Aksant, 2011.

Droz, Jacques. L'europe centrale. Évolution historique de l'idée de “Mitteleuropa". Paris: Payot, 1960.

Duroselle, Jean-Baptiste. L'idée d'Europe dans l'histoire. Paris: Denöel, 1965.

Emmerson, Charles. 1913: The World Before the Great War. London: Bodley Head, 2013.

Erni, Johannes. Die Europäische Union als Bedingung und Grundlage des dauernden Friedens. Zürich: Füssli, 1915.

Farrar, Lancelot L., Jr. Divide and Conquer. German Efforts to Conclude a Separate Peace, 1914-1918. New York: Columbia University Press, 1978.

Fisher, David J. Romain Rolland and the Politics of Intellectual Engagement. Berkeley, CA: University of California Press, 1988.

Fried, Alfred Hermann. Europäische Wiederherstellung. Zürich: Füssli, 1915.

Fuentes Codera, Maximiliano. "Ideas of Europe in Neutral Spain (1914-1918)." In Visions and Ideas of Europe, eds. D'Auria and Vermeiren.

Geary, Dick, ed. Labour and Socialist Movements in Europe before 1914. Oxford: Berg.

Gerwarth, Robert, and Erez Manela, eds. Empires at War, 1911-1923. Oxford: Oxford University Press, 2014.

Gerwarth, Robert. The Vanquished: Why the First World War Failed to End, 1917-1923. London: Allen Lane, 2016.

Giladi, Amotz. "L’idéologie panlatine et les méandres des rapports franco-italiens: le cas de la Revue des Nations Latines (1916-1919)." La Revue des revues 49 (2013): 44-56.

Górny, Maciej. “Eagle and Dwarf: Polish Concepts of East Central Europe, 1914-1921.” In Visions and Ideas of Europe, eds. D'Auria and Vermeiren.

Gregory, Adrian. "Beliefs and Religion." In The Cambridge History of the First World War, ed. Jay Winter, Cambridge: Cambridge University Press, 2014. III: Civil Society: 418-44.

Gross, Feliks. Crossroads of Two Continents: A Democratic Federation of East-Central Europe. New York: Columbia University Press, 1945.

Hájková, Dagmar. “Masaryk's Vision of New Europe, 1914-1918.” In Visions and Ideas of Europe, eds. D'Auria and Vermeiren.

Hanak, Harry. Great Britain and Austria-Hungary during the First World War: A Study in the Formation of Public Opinion. London: Oxford University Press, 1962.

Heeresgeschichtliches Museum, ed. Der unbekannte Verbündete - Bulgarien im Ersten Weltkrieg. Vienna: Heeresgeschichtliches Museum, 2009.

Hertrampf, Marina Ortrud M. "Romain Rolland (1866-1944)." In Klassiker des europäischen Denkens. Friedens- und Europavorstellungen aus 700 Jahren europäischer Kulturgeschichte, ed. Winfried Böttcher. Baden-Baden: Nomos, 2014: 470-76.

Hewitson, Mark, and Matthew D‘Auria, eds. Europe in Crisis: Intellectuals and the European Idea, 1917-1957. New York: Berghahn, 2012.

Hinz, Uta. "Humanität im Krieg? Internationales Rotes Kreuz und Kriegsgefangenenhilfe im Ersten Weltkrieg." In Kriegsgefangene im Europa des Ersten Weltkriegs, ed. Jochen Oltmer. Paderborn: Schöningh, 2006: 216-36. 
Hobsbawm, Eric. The Age of Empire, 1875-1914. London: Weidenfeld \& Nicolson, 1987.

Höhne, Steffen. "Imperiale Ambitionen und das Recht der kleinen Nationen. 'Mitteleuropa' bei Naumann und Masaryk." In "Mitteleuropa”. Geschichte eines transnationalen Diskurses im 20. Jahrhundert. eds. Jacques J. Lajarrige et al. Dresden: Thelem, 2011: 143-68.

Hollander, Neil. Elusive Dove: The Search for Peace during World War I. Jefferson, NC: McFarland \& Co., 2014.

Illies, Florian. 1913. Der Sommer des Jahrhunderts. Frankfurt/M.: S. Fischer, 2012.

Juzwenko, Adolf. "Leon Wasilewski’s Hopes for Federalism.” In Wilsonian East Central Europe: Current Perspectives, ed. John S. Micgiel. New York: Pilsudski Institute, 1995: 55-62.

Kann, Robert A. "Dynastic Relations and European Power Politics, 1848-1918." Journal of Modern History, 45/3 (1973): 387-410.

Kennedy, Ross. "Peace Initiatives.” In 1914-1918-online. International Encyclopedia of the First World War: http://dx.doi.org/10.15463/ie1418.10405

Kießling, Friedrich. Gegen den ,großen“ Krieg? Entspannung in den internationalen Beziehungen 1911-1914. Munich: Oldenbourg, 2002.

King, Francis. "Dilemmas of a 'Democratic Peace': World War One, the Zimmerwald Manifesto and the Russian Revolution." Socialist History. 48 (2015): 8-33.

Kipling, Rudyard, "France at War (1915)." In Rudyard Kipling, Kipling's War. Stroud: Amberley Publishing, 2014: 112-64.

Kirby, David. War, Peace, and Revolution: International Socialism at the Crossroads, 19141918. New York: St Martin's Press, 1986.

Klepsch, Michael. Romain Rolland im Ersten Weltkrieg. Ein Intellektueller auf verlorenem Posten. Stuttgart: Kohlhammer, 2000.

Kruizinga, Samuël. "Neutrality." In The Cambridge History of the First World War, ed. Jay Winter, Cambridge: Cambridge University Press, 2014. II: The State: 542-75.

Krumeich, Gerd. “'Gott mit uns'? Der Erste Weltkrieg als Religionskrieg.” In Gott mit uns. Nation, Religion und Gewalt im 19. und frühen 20. Jahrhundert, eds. Gerd Krumeich and Hartmut Lehmann. Göttingen: Vandenhoeck \& Ruprecht, 2000: 273-83.

Langer, Josef. “Tomáš Garrigue Masaryk (1850-1937).” In Klassiker des europäischen Denkens. Friedens- und Europavorstellungen aus 700 Jahren europäischer Kulturgeschichte, ed. Winfried Böttcher. Baden-Baden: Nomos, 2014: 431-38.

Lehmann, Hartmut. "International Solidarity in European and North American Protestantism before 1914 and after." In An Improbable War?, eds. Afflerbach and Stevenson: 256-70.

Little, Branden. "Humanitarian Relief in Europe and the Analogue of War, 1914-1918." In Finding Common Ground: New Directions in First World War Studies, eds. Michael Neiberg and Jennifer D. Keene. Leiden: Brill, 2010: 139-58.

Loth, Wilfried, and Marc Hanisch, eds. Erster Weltkrieg und Dschihad. Die Deutschen und die Revolutionierung des Orients. Munich: Oldenbourg, 2014.

Lüdke, Tilman. Jihad Made in Germany: Ottoman and German Propaganda and Intelligence Operations in the First World War. Münster: LIT, 2005.

Machovec, Milan. Tomáš G. Masaryk. transl. by Wilhelm Zrounek. Graz: Styria, 1969.

Mamatey, Victor S. The United States and East Central Europe, 1914-1918: A Study in Wilsonian Diplomacy and Propaganda. Port Washington: Kennikat, 1971.

Manela, Erez. The Wilsonian Moment: Self-Determination and the International Origins of Anticolonial Nationalism. Oxford: Oxford University Press, 2007. 
Masaryk, Tomáš G. Das neue Europa. Der slavische Standpunkt. transl. by Emil Saudek. Berlin: C.A. Schwetschke \& Sohn, [1920] 1991.

Mazower, Mark. Governing the World: The History of an Idea. London: Allen Lane, 2012.

Meyer, Henry Cord. Mitteleuropa in German Thought and Action, 1815-1945. The Hague: Nijhoff, 1955.

Morrow, John H. The Great War: An Imperial History. London: Routledge, 2004.

Nation, R. Craig. War on War: Lenin, the Zimmerwald Left, and the Origins of Communist Internationalism. Durham, NC: Duke University Press, 1989.

Naumann, Friedrich. Central Europe. transl. by Christabel M. Meredith. London: P.S. King \& Son, 1917.

Neiberg, Michael S. "Commanding through Armageddon: Allied Senior Leadership in World War I." In World War I Companion. ed. Matthias Strohn. Oxford: Osprey, 2013.

Nicolai, Georg Friedrich. Die Biologie des Krieges. Betrachtungen eines deutschen Naturforschers. Zürich: Füssli, 1917.

Nishikawa, Masao. Socialists and International Actions for Peace, 1914-1923. ed. Helmut Konrad and transl. by Masaki Watanabe. Berlin: Frank \& Timme, 2010.

Osterhammel, Jürgen. Die Verwandlung der Welt. Eine Geschichte des 19. Jahrhunderts. Munich: C.H. Beck, 2009.

Otte, T.G. "The Waning of the Monarchies: War, Revolution and Royal Diplomacy." In Russia's Great War and Revolution, 1914-1922: The Centennial Reappraisal, vol. International Affairs. ed. David McDonald et al. Bloomington, IN: Slavica [forthcoming].

Pegg, Carl H. Evolution of the European Idea, 1914-1932. Chapel Hill: University of North Carolina Press, 1983.

Planta, Gaudenz v. Europa auf dem Wege zur Einheit. Basel: Finckh, 1918.

Plaschka, Richard G., et al., eds. Mitteleuropa-Konzeptionen in der ersten Hälfte des 20. Jahrhunderts. Vienna: Verlag der Österreichischen Akademie der Wissenschaften, 1995.

Price, Morgan Philips. The Diplomatic History of the War

Prochasson, Christophe. "Intellectuals and Writers." In A Companion to World War One, ed. John Horne. Oxford: Wiley-Blackwell, 2010: 323-37.

Rasmussen, Anne. "Mobilising Minds." In The Cambridge History of the First World War, 3 vols., ed. Jay Winter, Cambridge: Cambridge University Press, 2014, III: Civil Society: 390-417.

Rolland, Romain. Journal des années de guerre 1914-1919. Notes et documents pour servir à l'histoire morale de l'Europe de ce temps, ed. Marie Romain Rolland. Paris: Michel, 1952.

Rolland, Romain. L'esprit libre. Paris: Michel, 1953.

Rosenbusch, Anne. "Spain's relief effort during the First World War", paper given at Neutrals at War 1914-1918. Comparative and Transnational Perspectives, Amsterdam, November 2015: https://www.historici.nl/sites/default/files/documents/Anne\%20Rosenbusch.pdf .

Roshwald, Aviel. Ethnic Nationalism and the Fall of Empires: Central Europe, Russia and the Middle East, 1914-1923. London: Routledge, 2001.

Rüegg, Emil. Die Vereinigten Staaten von Europa und Amerika und der Dauerfrieden. Zürich: Züricher Post, 1916.

Scholder, Klaus. The Churches and the Third Reich. transl. by John Bowden. Philadelphia: Fortress Press, 1988. I: Preliminary History and the Time of Illusions, 1918-1934.

Schweitzer, Patrick. Das Bulgarienbild im Spiegel der deutschen Presse der Jahre 1912-1918. 
Munich: GRIN, 2007.

Schweizerisches Komitee zum Studium der Grundlagen eines dauerhaften Friedensvertrages, ed. Die Grundlagen eines dauerhaften Friedensvertrages. Denkschrift. Olten: Trösch, 1915.

Seton-Watson, George H.N. and Christopher Seton-Watson. The Making of a New Europe. R.W. Seton-Watson and the Last Years of Austria-Hungary. London: Methuen, 1981.

Sondhaus, Lawrence. World War One: The Global Revolution. Cambridge: Cambridge University Press, 2011.

Soutou, Georges-Henri. L'or et le sang. Les buts de guerre économiques de la Première Guerre Mondiale. Paris: Fayard, 1989.

Spiering, Menno, and Michael Wintle, eds. Ideas of Europe since 1914: The Legacy of the First World War. Basingstoke: Palgrave Macmillan, 2002.

Steglich, Wolfgang. Die Friedensversuche der kriegführenden Mächte im Sommer und Herbst 1917. Quellenkritische Untersuchungen, Akten und Vernehmungsprotokolle. Stuttgart: Steiner, 1984.

Stein, Oliver. "'Wer das nicht mitgemacht hat, glaubt es nicht.' Erfahrungen deutscher Offiziere mit den bulgarischen Verbündeten 1915-1918." In Der Erste Weltkrieg auf dem Balkan. Perspektiven der Forschung, ed. Jürgen Angelow. Berlin: bebra, 2011: 271-87.

Stevenson, David. "The First World War and European Integration," The International History Review, 34/4 (2012): 841-63.

Stirk, Peter. A History of European Integration since 1914. London: Pinter, 1996.

Timmermann, Heiner. Friedenssicherungsbewegungen in den Vereinigten Staaten von Amerika und in Großbritannien während des Ersten Weltkrieges. Frankfurt/M.: Lang, 1978.

Tulechov, Valentina v. Tomas Garrigue Masaryk. Sein kritischer Realismus in Auswirkung auf sein Demokratie- und Europaverständnis. Göttingen: V\&R unipress, 2011.

Valiani, Leo. The End of Austria-Hungary. London: Secker and Warburg, 1973.

van der Linden, Wilhelmus H. The International Peace Movement during the First World War: In and Around the Dutch Anti-War Council, 1914-1919, Its Mediatory Work for a Speedy Peace, Its Central Organisation for a Durable Peace. Almere: Tilleul, 2006.

van Suchtelen, Nico. Het eenige redmiddel: een Europeesche Statenbond. Amsterdam: Maatschappij voor Goede en Goedkoope Lectuur, 1914.

Vermeiren, Jan. The First World War and German National Identity: The Dual Alliance at War. Cambridge: Cambridge University Press, 2016.

War Speeches by British Ministers, 1914-1916. London: Fisher Unwin, 1917.

Wettstein, Georg. Europas Einigungskrieg. Seine Ursachen und seine Resultate. Objektiver Ausblick eines Neutralen. Zürich: Lohbauer, 1914.

Will, Alexander. Kein Griff nach der Weltmacht. Geheime Dienste und Propaganda im deutschösterreichisch-türkischen Bündnis 1914-1918. Cologne: Böhlau, 2012.

Williams, Andrew J. "The Allies during the First World War and Paris Peace Conference." In France, Britain and the United States in the Twentieth Century, 1900-1940: A Reappraisal, ed. Andrew J. Williams. Basingstoke: Palgrave Macmillan, 2014: 56-93.

Zeman, Zbynek A.B. The Break-Up of the Habsburg Empire 1914-1918: A Study in National and Social Revolution. London: Oxford University Press, 1961.

Zurbrugg, A.W., ed. Not Our War: Writings Against the First World War. London: Merlin Press, 2014.

Zweig, Stefan. Romain Rolland: The Man and His Work. transl. by Eden and Cedar Paul. New 
York: Seltzer, 1921.

Zweig, Stefan. The World of Yesterday: An Autobiography. Lincoln, NE: University of Nebraska Press, 1964. 